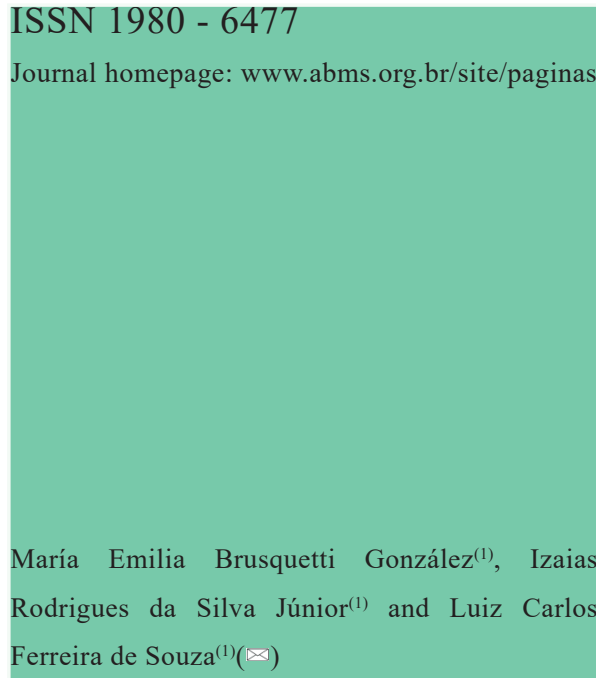

${ }^{1)}$ Universidade Federal da Grande Dourados

E-mail: embrusgon@hotmail.com,

izaias_jr@hotmail.com,

luizsouza@ufgd.edu.br.

$\varangle$ Corresponding author

How to cite

GONZÁLEZ, M. E. B.; SILVA JÚNIOR, I R.; SOUZA, L. C. F. Yield components and productivity of maize as a function of predecessor crop. Revista Brasileira de Milho e Sorgo, v. 19, e1168, 2020

\section{YIELD COMPONENTS AND PRODUCTIVITY OF MAIZE AS A FUNCTION OF PREDECESSOR CROP}

\begin{abstract}
Succession crops in no-tillage system can improve the soil attributes, thus favoring the growth and development of maize (Zea mays L.) and contributing to grain yield increment. The objective of this work was to verify the effect of succession crops on growth and development of maize planted in the summer and the influence on grain yield. For the study, a long-term experiment was implemented, beginning in September 2009, in dystroferric Red Latosol, on the Experimental Farm of the School of Agricultural Sciences of the Federal University of Grande Dourados (UFGD), located in the municipality of Dourados, Mato Grosso do Sul state. This article presents data collected from the 2017/2018 crop season. Randomized block design was used, with ten treatments and four replications. The treatments consisted of the crops preceding maize, such as millet (Pennisetum glaucum L.), oilseed rape (Brassica napus), oat (Avena sativa), safflower (Carthamus tinctorious), niger (Guizothia abyssinica), vetch (Vicia sativa), sunn hemp (Crotalaria juncea), and forage radish (Raphanus sativus). The predecessor crops positively influence dry matter mass of the aerial part of the plant, dry matter mass of 1000 grains, and productivity of the summer maize crop planted through the remains of straw (residues) of millet, oat, niger, sunn hemp, vetch and forage radish.
\end{abstract}

Keywords: Zea mays L., predecessor crop, no-tillage system.

\section{COMPONENTES DE PRODUÇÃO E PRODUTIVIDADE DO MILHO EM FUNÇÃO DA CULTURA ANTECESSORA}

Resumo - As culturas de sucessão no sistema de plantio direto podem melhorar os atributos do solo, favorecendo o crescimento e desenvolvimento da cultura do milho (Zea mays L.) e contribuindo para o aumento da produtividade dos grãos. Objetivou-se verificar o efeito das culturas no crescimento e desenvolvimento da planta de milho semeado no verão e sua influência na produtividade de grãos. Para o estudo, utilizouse um experimento de longa duração iniciado em setembro de 2009, implantado num Latossolo Vermelho Distroférrico na Fazenda Experimental da Faculdade de Ciências Agrárias da Universidade Federal da Grande Dourados, no município de Dourados em Mato Grosso do Sul, sendo apresentados neste artigo os dados referentes à safra 2017/2018. O delineamento experimental foi de blocos casualizados com dez tratamentos e quatro repetições. Os tratamentos foram constituídos pelas culturas antecessoras ao milho, como milheto (Pennisetum glaucum L.), canola (Brassica napus), aveia (Avena sativa), cártamo (Carthamus tinctorious), níger (Guizothia abyssinica), ervilhaca (Vicia sativa), crotalária (Crotalaria juncea) e nabo forrageiro (Raphanus sativus). As culturas antecessoras influenciam positivamente na massa da matéria seca da parte aérea da planta, na massa da matéria seca de 1.000 grãos e na produtividade da cultura do milho de verão semeado sobre a palhada remanescente de milheto, aveia, níger, Crotalária juncea, ervilhaca e nabo forrageiro.

Palavras-chave: Zea mays L., cultura antecessora, sistema de plantio direto. 
In Brazil, the grain production is currently estimated at 229.53 million tonnes for the 2017/18 crop season (CONAB, 2018). From that production, the highlights are the maize and soybean crops, which are responsible for $87 \%$ of the total amount produced.

No-tillage system (NTS) is defined as the conservation management practice that involves all recommended techniques to increase productivity, while continuously preserving or enhancing the environment. It is based on minimal soil disturbance, permanent ground cover, and crop rotation (HECKLER \& SALTON, 2002).

Crop rotation consists in alternating different crops, in the same area, in a regular and logical sequence (SOUZA, 2012). This technique, together with permanent ground cover and no soil disturbance, compose the NTS principles. Crop rotation contributes to improvement and maintenance of soil fertility; lower incidence of pests, diseases and weeds in the crop; greater crop diversification in the property; mitigation of failure risks associated with the agricultural activity; and maintenance and enhancement of crop productivity (FIDELIS et al., 2003). Lack of crop rotation determines the occurrence of chemical, physical and biological alterations in the soil, which may compromise the stability of the production system (FRANCHINI et al., 2011).

There are evidences of the potential of using crops such as oilseed rape, forage radish, safflower, crambe and niger for biodiesel production and as green manure. The use of those plants in the crop rotation system could significantly improve the yield of maize and soybean crops in traditionally producing regions.

In view of the above, the objective of this work was to evaluate the effect of predecessor crops on the growth and development of maize planted in the summer and the influence on grain yield.

\section{Material and Methods}

The experiment was carried out on the Agricultural Science Experimental Farm of the Federal University of Grande Dourados (FAECA/ UFGD), located in the municipality of Dourados, with the geographic coordinates being $22^{\circ} 14^{\prime} \mathrm{S}$ latitude, $54^{\circ} 49^{\prime} \mathrm{W}$ longitude and $458 \mathrm{~m}$ altitude. Data are from the $2017 / 18$ crop season, though the experiment started in 2009. According to the Köppen classification (ALVARES et al., 2013), the climate in the region is Aw type (characterized as tropical wet, with rainy summer and dry winter). The annual precipitation varies from 1200 to $1400 \mathrm{~mm}$, with average temperature of $22{ }^{\circ} \mathrm{C}$ and annual actual evapotranspiration between 1100 and $1200 \mathrm{~mm}$. Data for precipitation, minimum and maximum temperature throughout the experiment are shown in Figure 1.

The predominant soil in the experimental area is the dystroferric Red Latosol (SANTOS et al., 2013), with clay texture, varying natural fertility, deep, friable and presenting great homogeneity along the profile. The analysis of chemical soil attributes was carried out in the $0-20$ 
cm deep layer in the experimental area, presenting the following results: $\mathrm{pH}\left(\mathrm{CaCl}_{2}\right)=4.94 ; \mathrm{P}$ $($ Mehlich-1 $)=21.53 \mathrm{mg} \mathrm{dm}^{-3} ; \mathrm{H}++\mathrm{Al}^{3+}=6.79$ $\mathrm{cmol}_{\mathrm{c}} \mathrm{dm}^{-3} ; \mathrm{Al}^{3+}=0.07 \mathrm{cmol}_{\mathrm{c}} \mathrm{dm}^{3} ; \mathrm{K}^{+}=0.60$ $\left.\mathrm{cmol}_{\mathrm{c}} \mathrm{dm}^{-3} ; \mathrm{Ca}^{2+}=5.82 \mathrm{cmol}_{\mathrm{c}} \mathrm{dm}^{-3}\right) ; \mathrm{Mg}^{2+}=1.13$ $\mathrm{cmol}_{\mathrm{c}} \mathrm{dm}^{-3} ; \mathrm{CEC}=7.64 \mathrm{cmol}_{\mathrm{c}} \mathrm{dm}^{-3} ; \mathrm{V}=52.8 \%$; $\mathrm{OM}=29.19 \mathrm{~g} \mathrm{~kg}^{-1}$.

Randomized block design was used, with ten treatments and four replications. The treatments are presented in Table 1. Each experimental unit is $35 \mathrm{~m}$ long $\mathrm{x} 15 \mathrm{~m}$ wide, totaling an area of $525 \mathrm{~m}^{2}$.

In the experiment planning, it was determined that crop successions were to be evaluated along the years, taking into account that the climate conditions vary throughout the period. The results presented in this work refer to maize sown in the first crop season of the 2017/2018 agricultural year, in succession to oilseed rape (Brassica napus), safflower (Carthamus tinctorious), niger (Guizothia abyssinica), black oat (Avena strigosa Schreb), sunn hemp (Crotalaria juncea), vetch (Vicia sativa) and forage radish (Raphanus sativus).

The treatments consisted of predecessor crops, which were implemented in the autumnwinter season of the agricultural year, following the sowing and management recommendations specific for each species.

The maize cultivar used was Suprema SX-

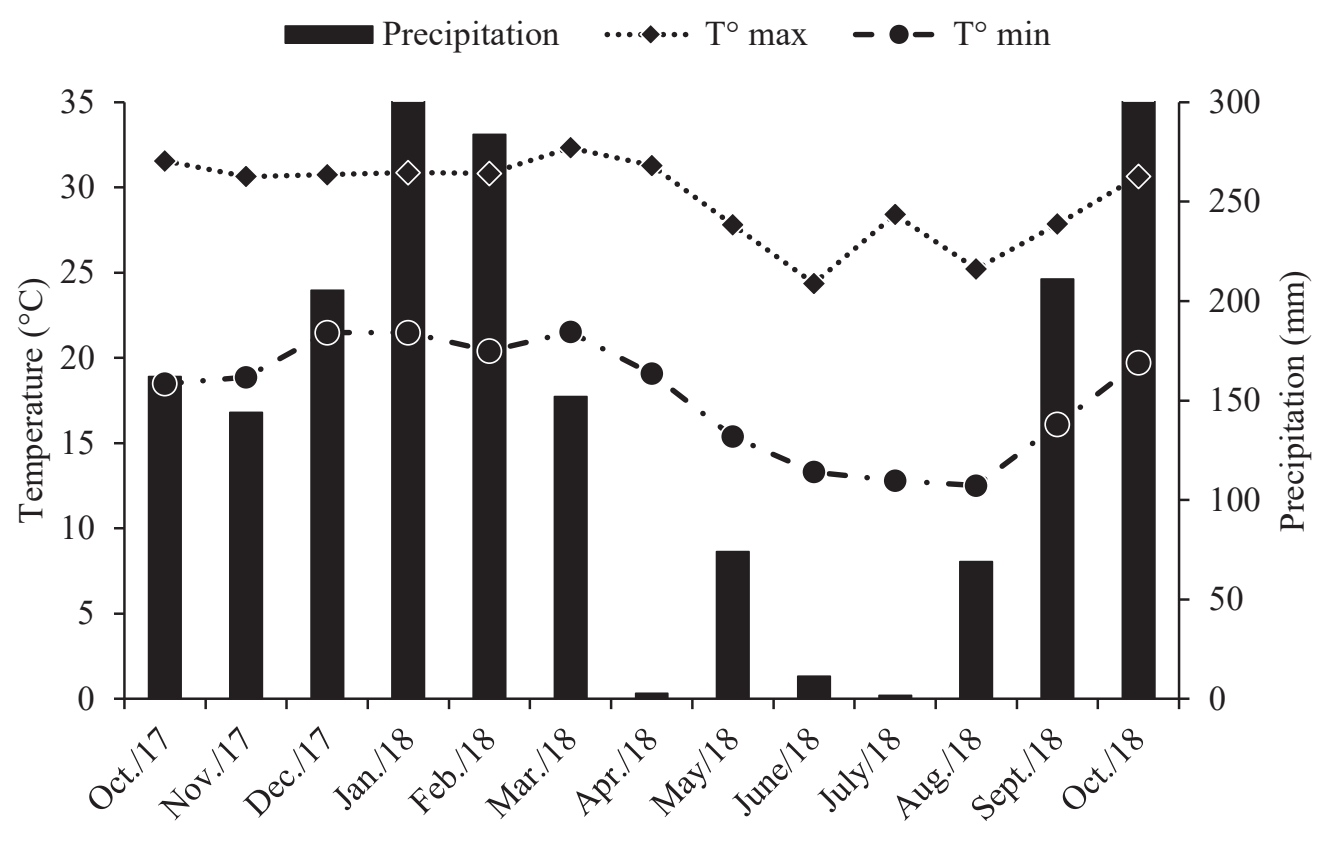

Figure 1. Precipitation, minimum and maximum temperature per 10-day period from October 2017 to October 2018, in Dourados - MS. Source: EMBRAPA (2018). 
Table 1. Ordered sequence of crop succession in the experiment, in the 2015/16, 2016/17, and 2017/18 crops seasons. Dourados / MS, 2018.

\begin{tabular}{|c|c|c|c|c|c|c|}
\hline \multicolumn{7}{|c|}{ Agricultural year } \\
\hline $\begin{array}{l}\text { Treat } \\
\text { ment }\end{array}$ & $\begin{array}{l}\text { Summer } \\
2015 / 16\end{array}$ & $\begin{array}{c}\text { Autumn/ } \\
\text { Winter } \\
2016\end{array}$ & $\begin{array}{l}\text { Summer } \\
2016 / 17\end{array}$ & $\begin{array}{c}\text { Autumn/ } \\
\text { Winter } \\
2017\end{array}$ & $\begin{array}{l}\text { Summer } \\
2017 / 18\end{array}$ & $\begin{array}{c}\text { Autumn/ } \\
\text { Winter } \\
2018\end{array}$ \\
\hline 1 & Maize & Brach. + Vetch & Soybean & Millet & Maize & Oilseed Rape \\
\hline 2 & Maize & Vetch + Maize & Soybean & Oilseed Rape & Maize & Millet \\
\hline 3 & Maize & Oilseed Rape & Soybean & B. Oat & Maize & Safflower \\
\hline 4 & Maize & Wheat & Soybean & Safflower & Maize & B. Oat \\
\hline 6 & Maize & Safflower & Soybean & Niger & Maize & W. Oat \\
\hline 7 & Maize & Crot. Ochroleuca & Soybean & Vetch + B. Oat & Maize & Sunn Hemp \\
\hline 8 & Maize & Crambe & Soybean & Sunn Hemp & Maize & Vetch + B. Oat \\
\hline 9 & Maize & Niger & Soybean & Vetch & Maize & Millet \\
\hline 10 & Maize & Vetch & Maize & Millet & Maize & Vetch \\
\hline 11 & Maize & $\begin{array}{l}\text { B. Oat + Vetch } \\
+ \text { Forage Radish }\end{array}$ & Maize & $\begin{array}{l}\text { B. Oat + Vetch } \\
+ \text { Forage Radish }\end{array}$ & Maize & $\begin{array}{c}\text { B. Oat }+ \text { Millet } \\
+ \text { Vetch }\end{array}$ \\
\hline
\end{tabular}

Brach.: Brachiaria; W. Oat: White Oat; B. Oat: Black Oat

7341VIP3, an early cycle single-cross hybrid with high yield potential, good grain quality, 252 $\mathrm{cm}$ height, and 1000-grain mass of $386 \mathrm{~g}$ (SYNGENTA, 2018).

Sunn hemp, niger, forage radish (IPR 116), black oat, vetch, oilseed rape (HYOLA 61), crambe (FMS Brilhante), and safflower were sown on the $15^{\text {th }}$ and $16^{\text {th }}$ of April 2017, with application of $200 \mathrm{~kg} \mathrm{ha}^{-1}$ of $07-20-20+0.3 \mathrm{~B}+$ $0.3 \mathrm{Zn}$. For the sowing of autumn-winter crops, a planter equipped with eight row units, spaced $0.4 \mathrm{~m}$ apart, was used. The seeding rate for wheat and oat was 60 seeds $\mathrm{m}^{-1}$, while 25 seeds $\mathrm{m}^{-1}$ was the rate applied to the other crops.
Maize was planted through winter crop residues (straw) on the $29^{\text {th }}$ of October 2017, in no-tillage system, with the use of a model planter equipped for direct sowing with seven row units spaced $0.9 \mathrm{~m}$ apart. At sowing, $400 \mathrm{~kg} \mathrm{ha}^{-1}$ of formulated fertilizer $(4-20-20+0.3 \% \mathrm{~B}+0.3 \%$ $\mathrm{Zn)}$ was used. Nitrogen topdressing was carried out when maize plants were in the V5 stage (RITCHIE, 1993), with $60 \mathrm{~kg} \mathrm{ha}^{-1} \mathrm{~N}$ applied in the furrows opened in the inter-row spacing, with the use of equipment suitable to that type of operation.

Weed control in the maize crop was performed by applying $0.7 \mathrm{~L} \mathrm{ha}^{-1}$ of nicossulfuron 
herbicide for control of broad and narrow leaves, and 3.0 L ha' ${ }^{-1}$ of atrazine herbicide for control of broad leaves. Control of fall armyworm (Spodoptera frugiperda) was done through two sprayings using insecticides that contain the active ingredient Flubendiamide in the dose of $70 \mathrm{ml} \mathrm{ha}^{-1}$ c.p. and Beta-Cyfluthrin + Imidacloprid in the dose of $500 \mathrm{ml} \mathrm{ha}^{-1}$ c.p. The first spraying was applied using Flubendiamide in the V6 stage (RITCHIE et al., 1993) and the second spraying was applied with the insecticide Beta-Cyfluthrin + Imidacloprid when the plants were in the V8 stage.

The characteristics assessed were dry matter mass of the aerial part, ear length, ear diameter, number of kernels per ear, dry matter mass of 1000 grains, and grain yield.

Experimental data were submitted to normality and homogeneity tests, in order to meet the assumptions of the analysis of variance. Subsequently, the data were submitted to analysis of variance to verify crop rotation effects. Means were compared through Scott-Knott test at 10\% probability, with the use of Agroestat statistical software (BARBOSA \& MALDONADO, 2015).

\section{Results and Discussion}

With regard to the niger and sunn hemp treatments, significant difference $(p<0.10)$ was observed for dry matter mass of the aerial part of maize plants in the different growth stages in relation to the other treatments (Table 2). Maize sown in succession to niger and sunn hemp presented greater accumulation of dry matter mass since the first evaluation in the V3 stage until the flowering (VT). In respect to the other treatments, regardless of the vegetative stage in which the evaluation was carried out, there were no differences as to dry matter contents. Therefore, it can be concluded that, in the plots where maize was sown through niger and sunn hemp residues, these crop residues were efficient for improvement of maize plant development.

The accumulation of maize dry matter takes place continuously until the grain maturity stage, with occurrence of a more intense accumulation period close to flowering (VT). After flowering, there is also the translocation of accumulated compounds from the vegetative part to the grains being formed (HAY et al., 1953; ODELAMA \& MILBOURN, 1972; FURLANI et al., 1977). That was observed in the results obtained in this research where the maximum accumulation occurred in the VT stage, at the beginning of flowering.

Von Pinho et al. (2009), when studying the process of macronutrient intake and dry mass accumulation in maize plant, verified linear responses as to dry mass accumulation in different maize genotypes during the crop cycle.

Andrade et al. (1975), Furlani et al. (1977), Vasconcelos et al. (1983) and Pinho et al. (2009) state that maize plant growth is a linear function of time and the curve of dry matter weight of the entire plant is slightly sigmoid. According to these authors, that curve is practically linear 
Table 2. Mean values for dry matter mass of the aerial part $\left(\mathrm{g}_{\text {plant }}{ }^{-1}\right)$ of maize plant as a function of the predecessor crop. Dourados - MS, 2017/18.

\begin{tabular}{lcccc}
\hline \multicolumn{1}{c}{ Treatments } & V3 & V6 & V8 & VT \\
\hline Millet & $28 \mathrm{~b}$ & $189 \mathrm{~b}$ & $1001 \mathrm{~b}$ & $1645 \mathrm{~b}$ \\
Oilseed rape & $28 \mathrm{~b}$ & $189 \mathrm{~b}$ & $1009 \mathrm{~b}$ & $1637 \mathrm{~b}$ \\
Black oat & $28 \mathrm{~b}$ & $180 \mathrm{~b}$ & $1037 \mathrm{~b}$ & $1655 \mathrm{~b}$ \\
Safflower & $28 \mathrm{~b}$ & $188 \mathrm{~b}$ & $1056 \mathrm{~b}$ & $1681 \mathrm{~b}$ \\
Niger & $29 \mathrm{a}$ & $213 \mathrm{a}$ & $1131 \mathrm{a}$ & $1930 \mathrm{a}$ \\
Vetch + Black oat & $28 \mathrm{~b}$ & $188 \mathrm{~b}$ & $1099 \mathrm{~b}$ & $1673 \mathrm{~b}$ \\
Sunn hemp & $29 \mathrm{a}$ & $212 \mathrm{a}$ & $1173 \mathrm{a}$ & $1960 \mathrm{a}$ \\
Vetch & $28 \mathrm{~b}$ & $180 \mathrm{~b}$ & $1047 \mathrm{~b}$ & $1673 \mathrm{~b}$ \\
Forage radish & $28 \mathrm{~b}$ & $188 \mathrm{~b}$ & $1068 \mathrm{~b}$ & $1674 \mathrm{~b}$ \\
Forage radish + Oat + Vetch & $28 \mathrm{~b}$ & $188 \mathrm{~b}$ & $1053 \mathrm{~b}$ & $1647 \mathrm{~b}$ \\
\hline CV $(\%)$ & 1.45 & 4.18 & 5.49 & 2.63 \\
\hline Overall mean & 28.05 & 191 & 1067 & 1717 \\
\hline
\end{tabular}

from 40 to 80 days after emergence (DAE), with maximum accumulation occurring between 100 and 110 days after emergence (DAE), which is the moment when the total plant weight starts to decrease, probably due to the fall of senescent leaves.

The highest productivity was obtained when maize was sown in succession to sunn hemp $\left(10,058 \mathrm{Kg} \mathrm{ha}^{-1}\right)$, though not differing when maize was sown after millet, black oat, niger, vetch and forage radish (Table 3).

According to data provided by Conab (2018), the productivity of maize was $8,500 \mathrm{~kg}$ $\mathrm{ha}^{-1}$ in the first crop season of 2017/2018 in Mato Grosso do Sul, which is lower than the productivity obtained for maize planted in succession to sunn hemp, niger, oat, millet, forage radish and hairy vetch. Those results indicate the importance of crop rotation to the maize crop, associated with good soil management throughout the nine-year period of the experiment implementation, with no-tillage system applied and the use of a variety of species.

Besides the good soil fertility found in the experimental area, $16 \mathrm{~kg} \mathrm{ha}^{-1}$ of $\mathrm{N}, 80 \mathrm{~kg} \mathrm{ha}^{-1}$ of $\mathrm{P}_{2} \mathrm{O}_{5}$ and $\mathrm{K}_{2} \mathrm{O}$ were used, respectively, at maize sowing. In addition, $60 \mathrm{~kg} \mathrm{ha}^{-1}$ of $\mathrm{N}$ were surface applied in the V4 stage of maize growth, which enhanced the yields obtained in the experiment, in association with good rainfall distribution in the vegetative and reproductive stages (Figure 1).

In a research developed by Pilletti (2015), the forage radish, sunn hemp, safflower and oat crops produced more than 6 tonnes of straws 
Table 3. Mean values for ear length $(\mathrm{cm})$, ear diameter $(\mathrm{mm})$, number of kernels per ear, dry mass of 1000 grains $(\mathrm{g})$, and yield $\left(\mathrm{kg} / \mathrm{ha}^{-1}\right)$ of maize plant as a function of the predecessor crop. DouradosMS, 2017/2018.

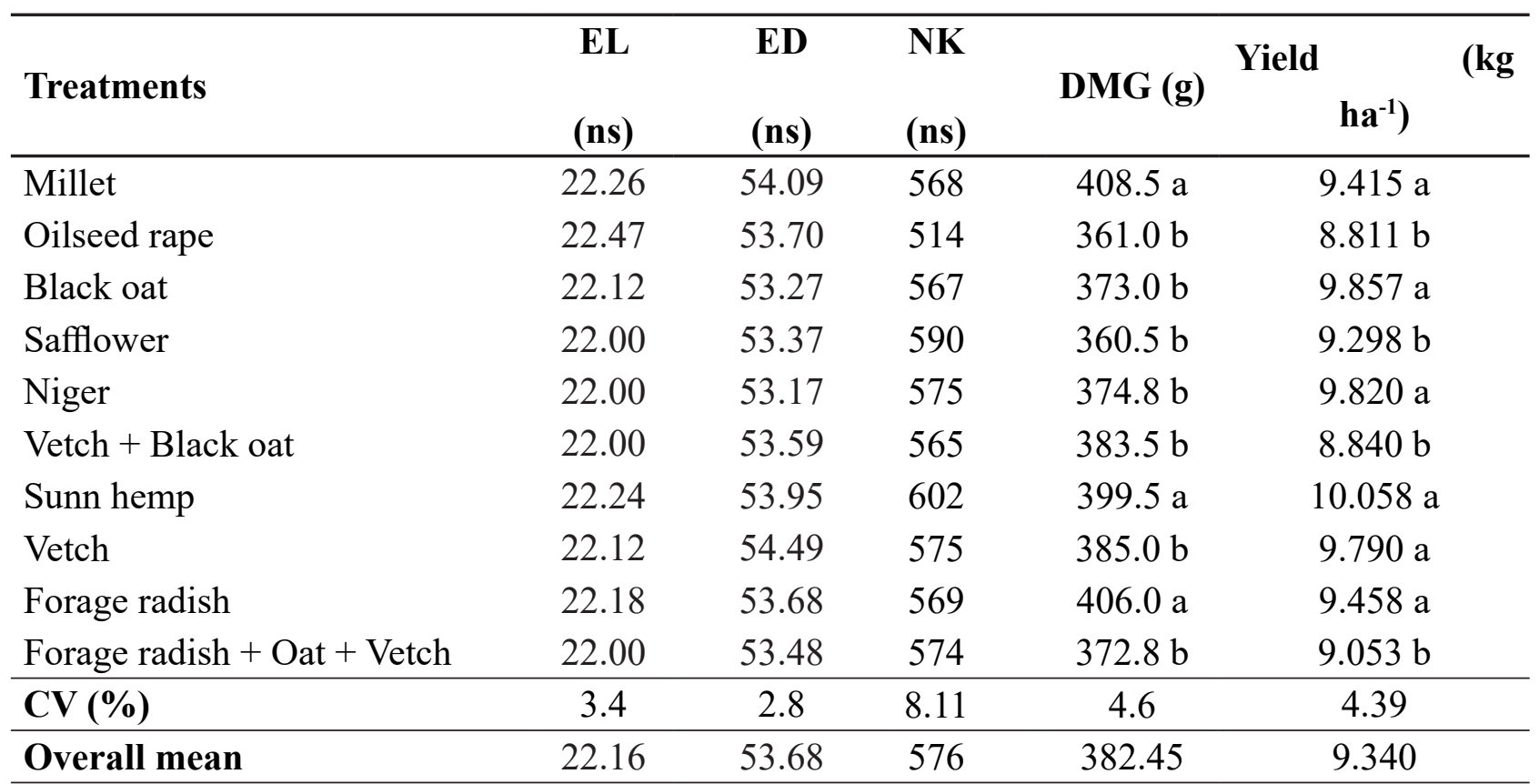

Means followed by the same letter in the column do not differ among one another as per Scott-Knott test $(\mathrm{p}<0.10)$; ns- not significant; EL: ear length; ED: ear diameter; NK: number of kernels per ear; DMG: dry mass of 1000 grains.

(crop residues), with the forage radish presenting the lowest $\mathrm{C} / \mathrm{N}$ ratio (13.5) and the oat showing the highest $\mathrm{C} / \mathrm{N}$ ratio (32).

Freitas (2014), when studying the effect of crop rotation on maize yield components, concluded that the maize sown in succession to niger, crambe, oilseed rape and sunflower presents higher grain yield, as long as the climate conditions allow the plant to express its productive capacity. Souza et al. (2016), when studying the crop rotation and succession with oleaginous plants in Dourados/MS, also obtained higher yield when maize was sown in succession to niger.

In a research developed by Bergamin (2012), the occurrence of macroporosity increment and lower density in the $0-10 \mathrm{~cm}$ soil layer was verified in those plots where niger was planted in succession to soybean or maize.

Upon evaluation of the yield potential of maize cultivated through oleaginous plant residues, associated with surface-applied nitrogen fertilizer, Pedrotti et al. (2012) observed higher productivity of maize in succession to forage radish and lower productivity in the plots where the predecessor crops were safflower and 
crambe.

Sunn hemp is a very important leguminous plant in agriculture because it is regarded as an excellent soil nitrogen-fixing species. According to Miotto et al. (2007), sunn hemp presents differential decomposition rate, where the stem fraction decomposes more rapidly than the leaf + pod fraction, thus favoring ground cover and nutrient mineralization, which provides higher cycling and release of elements that are essential to plant nutrition.

\section{Conclusions}

Predecessor crops influence dry matter mass of the aerial part of the plant, dry matter mass of 1000 grains, and productivity of maize crop.

Summer maize planted through straw (residues) of millet, black oat, niger, sunn hemp, vetch and forage radish presents the highest yields.

\section{Acknowledgments}

To the Brazilian National Council for Scientific and Technological Development (CNPq), for the financial support provided for execution of this research; and to everyone who made possible the development of this work.

\section{References}

ADELANA, B. O.; MILBOURN, G. M. The growth of maize. II. Dry-matter partition in three maize hybrids. Journal Agricultural Science, v. 78, n. 1, p. 73-78, 1972. DOI: 10.1017/ S0021859600087712.

ALVARES. C. A.; STAPE, J. L.; SENTELHAS, P. C.; GONÇALVES, J. L. de M.; SPAROVEK, G. Köppen〉s climate classification map for Brazil. Meteorologische Zeitschrift, v. 22, n. 6, p. 711728, 2013. DOI: 10.1127/0941-2948/2013/0507.

ANDRADE, A. G.; HAAG, H. P.; OLIVEIRA, G. D.; SARRUGE, J. R. Acumulação diferencial de nutrientes em cinco cultivares de milho (Zea mays L.). II - acumulação de micronutrientes. Anais da Escola Superior de Agricultura Luiz de Queiroz, v. 32, p. 151-171, 1975. DOI: 10.1590/S0071-12761975000100012.

BARBOSA, J. C.; MALDONADO JÚNIOR, W. Experimentação agronômica \& AgroEstat: sistema para análises estatísticas de ensaios agronômicos. Jaboticabal: Multipress, 2015.

\section{BERGAMIN, A. Indicadores da qualidade} estrutural de um Latossolo cultivado com oleaginosas em sistema de sucessão com soja e milho. 2012. 76 f. Tese (Doutorado em Produção Vegetal) - Universidade Federal da Grande Dourados, Dourados, MS, 2012.

FIDELIS, R. R.; ROCHA, R. N. C.; LEITE, U. T.; TANCREDI, F. D. Alguns aspectos do plantio direto para a cultura de soja. Bioscience 
Journal, v. 19, n. 1, p. 23-31, 2003.

FRANCHINI, J. C.; COSTA, J. M.; DEBIASI, H.; TORRES, E. Importância da rotação de culturas para produção agrícola sustentável no Paraná. Embrapa Soja: Londrina: Embrapa Soja, 2011. 52 p. (Embrapa Soja. Documentos, 327).

FREITAS, M. E. Estudo de sistemas de produção de grãos de espécies oleaginosas para produção de óleo vegetal em rotação de culturas com soja e milho. 2014. 83 f. Dissertação (Doutorado em Produção Vegetal) - Universidade Federal da Grande Dourados, Dourados, MS, 2014.

FURLANI, P. R.; HIROCE, R.; BATAGLIA, O. C.; SILVA, W. J. Acúmulo de macronutrientes, de silício e de matéria seca por dois híbridos simples de milho. Bragantia, v. 36, n. 1, p. 223-229, 1977. DOI: $10.1590 /$ S0006-87051977000100022.

HeCKleR, J. C.; SAlton, J. C. Palha: fundamento do Sistema Plantio Direto. Dourados: Embrapa Agropecuária Oeste, 2002. 26 p. (Embrapa Agropecuária Oeste. Coleção sistema plantio direto, 7).

HAY, R. E.; EATLEY, E. B.; DETURK, E. E. Concentration and translocation of nitrogen compounds in the corn plant (Zea mays) during grain development. Plant Physiology, v. 28, n. 4, p. 606-621, 1953. DOI: 10.1104/pp.28.4.606.

MIOTTO, A.; PREDEBON, R.; WILDNER, L.
P.; DENARDIN, R. B. N.; DENARDIN, L. C.; GIURATTI, A. Comportamento da cobertura de solo durante a decomposição da fitomassa de Crotalaria juncea L. em condições de campo. In: CONGRESSO BRASILEIRO DE CIÊNCIA DO SOLO, 31., 2007, Gramado. Conquistas e desafios da ciência do solo brasileira: anais. Gramado: Sociedade Brasileira de Ciência do Solo, 2007.

PEDROTTI, M. C.; SOUZA, L. C. F.; FREITAS, M. E.; DARBELO, L. T.; TANAKA, K. S. Potencial produtivo do milho cultivado sobre resíduos de oleaginosas e da adubação nitrogenada em cobertura. In: CONGRESSO NACIONAL DE MILHO E SORGO, 29., 2012, Águas de Lindóia. Diversidade e inovações na era dos transgênicos: resumos expandidos. Campinas: Instituto Agronômico; Sete Lagoas: Associação Brasileira de Milho e Sorgo, 2012. p. 1954-1959.

PILETTI, L. Desempenho agronômico de milho e soja em diferentes sistemas de rotação de culturas. 2016. 76 f. Tese (Doutorado em Produção Vegetal) - Universidade Federal da Grande Dourados, Dourados, MS, 2016.

REUNIÃO TÉCNICA ANUAL DE PESQUISA DE MILHO, 62., 2017.; REUNIÃO TÉCNICA ANUAL DE PESQUISA DE SORGO, 45., 2017, Sertão, RS. Indicações técnicas para o cultivo de milho e de sorgo no Rio Grande do Sul: safras 2017/2018 e 2018/2019. Brasília, 
DF: Embrapa, 2017. 209 p.

RITCHIE, S. W.; HANWAY, J. J.; BENSON, G. O. How a corn plant develops. Ames: Iowa State University of Science and Technology, 1993. 26 p. (Special Report, v. 48).

SANTOS, H. G. dos; JACOMINE, P. K. T.; ANJOS, L. H. C. dos; OLIVEIRA, V. A. de; LUMBRERAS, J. F.; COELHO, M. R.; ALMEIDA, J. A. de; CUNHA, T. J. F.; OLIVEIRA, J. B. de. Sistema brasileiro de classificação de solos. 3. ed. rev. e ampl. Brasília, DF: Embrapa, 2013. 353 p.

SOUZA, G.; RIOS, E.; LIMA, G.; SANTOS, D. Aporte de nitrogênio foliar em leguminosas com potencialidade para adubação verde. In: REUNIÃO NORDESTINA DE CIÊNCIA DO SOLO, 3., 2016, Aracaju. Ciência do solo: integração e uso do conhecimento para uma agricultura sustentável no Nordeste: anais. Aracaju: Embrapa Tabuleiros Costeiros: Unit, 2016a.
SOUZA, C. M. de; PIRES, F. R.; PARTELLI, F. L.; ASSIS, R. L. Adubação verde e rotação de culturas. Viçosa, MG: Universidade Federal de Viçosa, 2012. 108 p.

SOUZA, L. C. F. de; LUIS, A. J.; PILETTI, L. M. M. da S. Características agronômicas do milho em função da cultura antecessora em sistema plantio direto. Revista Brasileira de Milho e Sorgo, v. 15, n. 2, p. 272-280, 2016b. DOI: 10.18512/1980-6477/rbms.v15n2p272-280.

SYNGENTA. Supremo Víptera3: características. Disponível em: <https://www.portalsyngenta. com.br/sementes-milho-supremo-viptera-3>. Acesso em: 10 out 2018.

VASCONCELLOS, C. A.; BARBOSA, J. V. A.; SANTOS, H. L. dos; FRANÇA, G. E. de. Acumulação de massa seca e de nutrientes por duas cultivares de milho com e sem irrigação suplementar. Pesquisa Agropecuária Brasileira, v. 18, n. 8 , p. 887- 901, 1983.

VON PINHO, R. G.; BORGES, I. D.; PEREIRA, J. L. A. R.; REIS, M. C. Marcha de absorção de macronutrientes e acúmulo de matéria seca em milho. Revista Brasileira de Milho e Sorgo, v. 8, n. 2, p. 157-173, 2009. DOI: 10.18512/1980-6477/rbms.v8n2p157-173. 